Volume 10, Issue 6, November-December 2019, pp. 33-44, Article ID: IJM_10_06_004

Available online at http://iaeme.com/Home/issue/IJM?Volume $=10 \&$ Issue $=\overline{6}$

Journal Impact Factor (2019): 9.6780 (Calculated by GISI) www.jifactor.com ISSN Print: 0976-6502 and ISSN Online: 0976-6510

\title{
EMPLOYEE COMPETENCIES AS THE PREDICTORS OF THE PERFORMANCE MANAGEMENT SYSTEM: AN EMPIRICAL STUDY IN IT ENABLED SERVICE COMPANIES AROUND HYDERABAD
}

\author{
Mruthyanjaya Rao and KDV Prasad* \\ Department of Management Studies, RTM Nagpur University, Nagpur, Maharashtra, India
}

\section{Dr Rajesh Vaidya}

Assistant Professor- Integrated MBA, Department of Management Technology,

Shri Ramdeobaba College of Engineering \& Management, Nagpur, India

*Corresponding Author: prasadkanaka2003@yahoo.co.in

*All the Authors Equally Contributed

\begin{abstract}
The authors report the results of an empirical research study carried out, how the employee competencies will effect Performance Management System in IT Enabled Service companies. A survey of 900 employees working in IT Enabled Service companies around Hyderabad Metro consisting of 550 men and 350 women employees using a structured questionnaire was carried out. The study empirically measured the effect of four independent variables, the employee competencies- personal competencies, knowledge level competencies, job-related competencies and communication and interpersonal competencies on a dependent variable performance management system in IT Enabled Services companies. The reliability of the survey instrument and internal consistencies were measured using reliability statistic Cronbach alpha and the Cronbach alpha values ranged between 0.70 to 0.86 for men and 0.67 to 0.82 for women. The results of the multiple regression analysis reveal statistically significant differences indicating that four independent variables are significant predictors of performance management system. Statistically significant gender differences were observed and men and women employees are significantly influencing performance management system in IT Enabled companies, however there are no statistically significant different among the different age groups of employees.
\end{abstract}

Keywords: Performance Management System, Cronbach alpha, multiple regression, employee competencies, performance appraisal 
Cite this Article: Mruthyanjaya Rao, KDV Prasad and Dr Rajesh Vaidya, Employee Competencies as the Predictors of the Performance Management System: An Empirical Study in it Enabled Service Companies around Hyderabad, International Journal of Management, 10 (6), 2019, pp. 33-44.

$\mathrm{http}: / /$ iaeme.com/Home/issue/IJM?Volume $=10 \&$ Issue $=6$

\section{INTRODUCTION}

Performance management system (PMS) is a methodological approach to evaluate the performance of employees in any organization. The PMS enables the organization to see whether the there is any deviation in the performance of employees which effects the organizations mission, vision and goals, and the PMS in most of the organizations is aligned with an its vision, and goals, priorities and objectives. The PMS is basis of all the organisations to identify the current and future competency gaps. PMS also helpful in conflict management, identifying training needs, mentoring employees and for optimizing the use of human resources and resource pools [1]. The PMS process can be used as a single function or unit for a whole organization and it is must to measure the employee performance against the vision, mission, goals and objectives of an organisation. Apart from the measuring the employee performance PMS also focus on aligning the strategic objectives with employee performance, documentation, on time product delivery, actionable feedback and making organization goals challenging and interesting.

In general, the performance measurement is done on yearly basis for individual employees and sometimes self-assessment by employees and at next level by his/her immediate peer will evaluate the as per the PMS, in most of the organisations. After the measuring the performance of an employee using PMS, the rewards, praises, and appropriate suggestions to the employees will be given, if the deviations if any, were observed in the employee performance. The benefits of the performance management system are: its provide a repository of data and knowledge to identify the knowledge gaps of the employees, identify training needs, motivates the employees to learn new assignment in pursuit of professional perfection. The system also provides a mechanism to address the grievances, conflict handling, and growth and development [2]

Performance management system is a strategic tool for human resource management and for the employees to achieve their desired objectives and through which the organizations will achieve its goals. The PMS will be linked to employee performance and organization goals [3]. The transformation of PMS and its measurements started during 1990s [4]. Furnham [5] noticed that performance management system application in China industry during the third century however, PMS systems were modernized during $18^{\text {th }}$ and $19^{\text {th }}$ centuries in American and Britain armies. Literature further indicates that performance management during the industrial revolution was simple and crude. The author further reported that most of the performance systems was used in big companies however, this were brought in the public service systems at full level during 1980s and 1990.

\section{REVIEW OF LITERATURE}

In the recent past and since last three decades the performance management systems were more formalized and PMS metrics were established. Several issues like talent management, recruitment management, rewards systems were included in the PMS. The new revolution in performance management system and its measurement began last two decades [4]. Furnham [5] reported that performance management system was available even during third century in some countries and during $18-19^{\text {th }}$ centuries the system was refurbished to suit the needs of organizations. However, in the recent past PMS was more formalized and smoothed and several old theories were absorbed into the performance management system with new avenues. 
Several researchers reported their studies on the performance management system. There is a need to have systematic management approach to manage the employee in the organizations as traditional systems were changed and modified several times. Further, PMS must provide relevant, specific and required information in timely for decision making and planning [6].

The impact of the performance management and appraisals will have significant impact on productivity, and financial revenues of an organization. The greater the performance of the employees directly result in higher profits, stronger stock markers and healthier cash flows [7]. The behavior of the employee is the major factor in designing and implementing the performance management systems successfully [8]. Understanding the employee behavioral attitudes is a major factor for successful implementation of the PMS [9]. The performance management involves listing out various objective on individual and organizational level, rewards, learning and development strategies, career and succession planning and OD interventions [10]. The performance management system ensures the employees, actually what is expected from them, job knowledge required, capacity development and an opportunity to contribute as an individual and team to the organization's vision and mission Watkins [11] with his Nigerian study reported that both public and private sectors should have PMS system. The PMS is very important for organization as the system facilitates to achieve the organization goals and develop performance oriented culture [12]. Both the internal and external circumstances can influence the performance management system. The internal factors are commitment of the management, resources, culture, employee and leadership engagement. Whereas external factors include citizens, stakeholders, unions, legal systems [13]. The human resources are an important assets of any organization and well management of human resources is essential for organizations growth, development and improved productivity. It's the responsibility of top management through PMS to identify the gaps between the competencies required and actual competencies needed to carry out an assignment [14].

The researchers carried out several regression studies. Mamatha and Prasad [15] reported the employee performance as a function of social support and coping with a case study with reference agricultural research sector employees, where increased social support and coping will improve the employee performance. Occupational stress factors also effect the performance as reported by Prasad et al., [16] with their empirical study referring to CBSE affiliated school teachers in Hyderabad. Prasad et al., [17] studied the association among occupational stress factors and its effect on employee performance among Agricultural Research Sector employees in Hyderabad and reported that several factors effect the employee performance. Several studies were conducted on occupational stress and its effect employee performance information technology sectors and reported medium level effect of performance with stress (Prasad et al., [16][17][18]). Turóczy Zsuzsannaa and Liviu Marian [19] carried out Emerging Markets Queries in Finance and Business Multiple regression analysis of performance indicators in the ceramic industry and reported three variables, self-financing capacity, return on equity, and degree of technical endowment, are the significant predictors to the performance in ceramic industry

Based on the research reviews the authors could not find a single study on the effect of performance management system with employee competencies using regression analysis. To fill this research gap the authors made a sincere attempt with this empirical survey to study the effect of employee competencies on PMS.

\section{OBJECTIVES AND HYPOTHESES}

Background and reason for this research: There are very limited studies to predict the outcome of PMS based on the employee competencies using multiple regression models and in particular 
studies related to performance management system. Therefore, this study was pursued using a survey on the employee of IT Enabled companies

Objective: To see if there any effect of employee personal competencies on performance management system in ITES enabled companies around Hyderabad Metro

Based on the identified problem, the following hypotheses are formed

$\mathrm{H}_{01}$ : Employee personal competencies does not influence the performance management system of IT Enabled Service companies

$\mathrm{H}_{11}$ : Employee personal competencies influence the performance management system of IT Enabled Service companies

$\mathrm{H}_{02}$ : Employee knowledge level competencies does not influence the performance management system of IT Enabled Service companies

$\mathrm{H}_{12}$ : Employee knowledge level competencies influence the performance management system of IT Enabled Service companies

$\mathrm{H}_{03}$ : Employee job-related competencies does not influence the performance management system of IT Enabled Service companies

$\mathrm{H}_{13}$ : Employee job-related competencies influence the performance management system of IT Enabled Service companies

$\mathrm{H}_{04}$ : Employee communication and interpersonal competency does not influence the performance management system of IT Enabled Service companies

$\mathrm{H}_{14}$ : Employee communication and interpersonal competency the performance management system of IT Enabled Service companies

Conceptual framework: The proposed framework was adopted based on the performance management system framework provided by Writinghub, UK [20]. The framework formulated is presented in figure 1 .

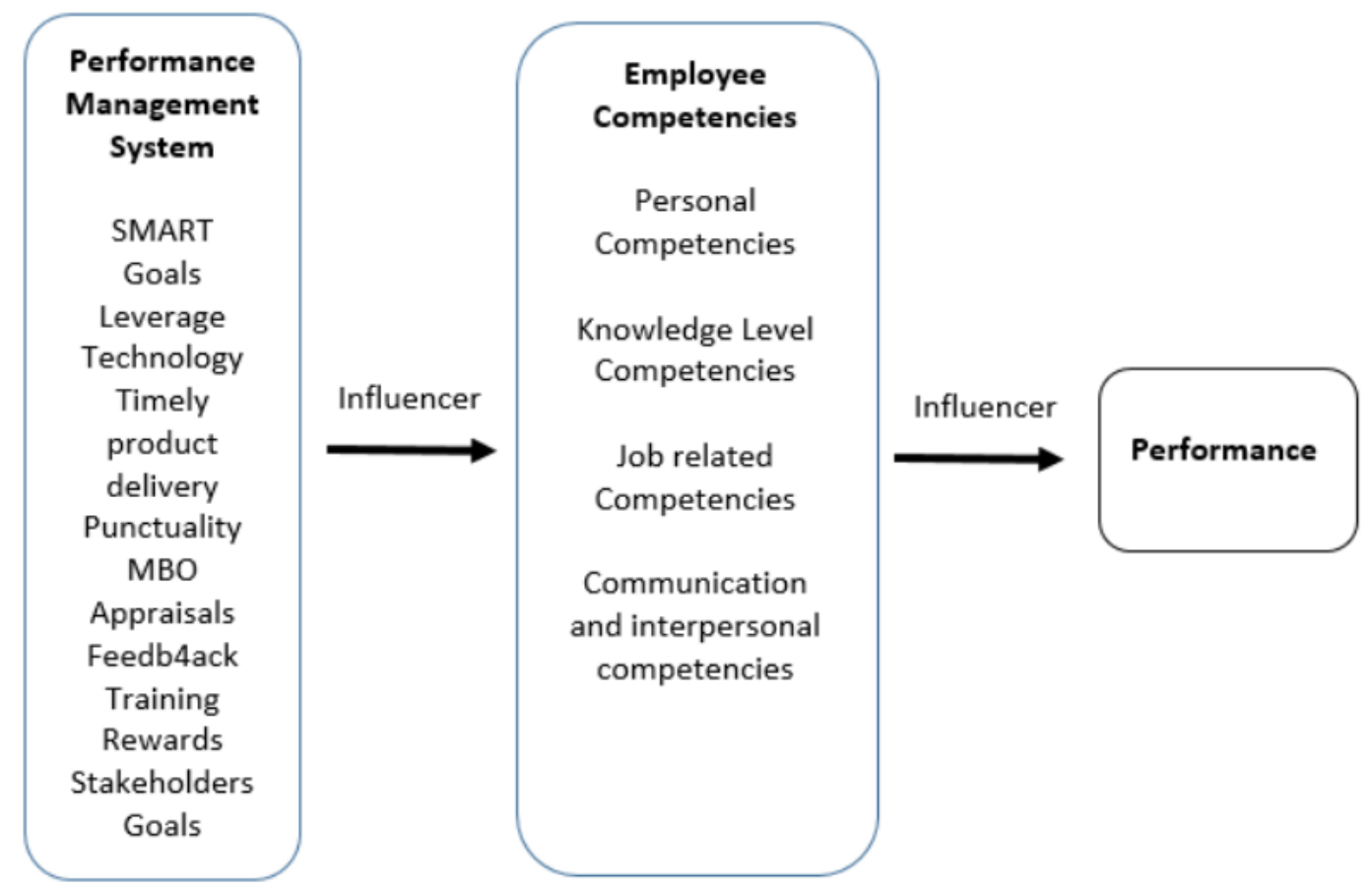

Figure 1: Conceptual Framework Performance Management System (Source: Writing Hub, UK, 2015) 


\section{RESEARCH METHODOLOGY}

Sample size: A sample size of 900 was selected using simple random sampling where each member of the subset has equal probability of being chosen and data consists of 549 male and 375 female employees. The demographic characteristics of study variables are presented in Table 1.

Table 1. Age groups of employees (in year)

\begin{tabular}{|c|c|c|}
\hline Age Group & Number & Percent \\
\hline $20-26$ & 145 & 16.1 \\
\hline $27-30$ & 170 & 18.9 \\
\hline $31-40$ & 151 & 16.8 \\
\hline $41-50$ & 150 & 16.7 \\
\hline $51-60$ & 150 & 16.7 \\
\hline 60 and above & 134 & 14.8 \\
\hline Total & 900 & 100 \\
\hline Male $=\mathrm{n}(550) ;$ female $\mathrm{n}(350)=$ total $=900$ & \\
\hline
\end{tabular}

Research instrument and data gathering: The research instrument used for this empirical study is a structured undisguised questionnaire using 2 scales a) the performance management system scale with 13 factors measured on Likert-type 5-point scale with Extremely Relevant with score of 5 to Not at all Relevant with score of 0 ; b) personal competencies 5 factors, knowledge level competencies 3 factors, job-related competency 4 factors, communication and interpersonal competency and for all the competencies the scale is Excellent with a score of 5 to Considerable Improvement needed with a score of 1 on Likert-type scale. The other information on demographic variable like gender, age, qualifications, positon, marital details also gathered. All the study factors were presented in Table 2.

Table 2: Detail description of the factors in empirical study

\begin{tabular}{|c|l|l|}
\hline SI No & \multicolumn{1}{|c|}{ Factors } & \multicolumn{1}{c|}{ Items } \\
\hline 1 & Performance Management & $\begin{array}{l}\text { 13: Efficient utilization of available resources, Maintenance of } \\
\text { good quality standards, Maintenance of safety standards, Clearly } \\
\text { intimating employees with work deadlines, On time product } \\
\text { delivery, Punctuality maintained by staff members, Awareness } \\
\text { among employees about their work quality impact, Regular } \\
\text { training of employees, Regular performance assessments of } \\
\text { employees, Recognition and reward for good performance, } \\
\text { Consideration of employees job satisfaction; Performing corporate } \\
\text { social liabilities; Employee capability to differentiate among } \\
\text { personal and organizational objectives }\end{array}$ \\
& & $\begin{array}{l}5: \text { Ability to state opinions firmly, Gaining trust of co-workers, } \\
\text { Honest interaction with co-workers, Self-sufficiency in performing } \\
\text { professional duties, Handling work pressure with calmness }\end{array}$ \\
\hline 3 & Personal Competencies & $\begin{array}{l}3: \text { Work-related knowledge, Quality awareness, Knowledge about } \\
\text { department-related functionalities }\end{array}$ \\
\hline 4 & Knowledge Level & $\begin{array}{l}\text { 4: Clear presentation of ideas to the target group, Quick decision } \\
\text { taking ability; Strive for excellence; Ability to share opinions with } \\
\text { co-workers for a constructive agreement }\end{array}$ \\
\hline 5 & Job-Knowledge Competencies \\
& & $\begin{array}{l}4: \text { Ability to listen patiently to others, Ability to respond with clear } \\
\text { ideas, Ability to persuade others for task completion, Sensitivity } \\
\text { towards different ongoing activities in workplace }\end{array}$ \\
\hline 6 & Communication and &
\end{tabular}


Data analysis: For our empirical investigation we have applied statistical methods to analyse the data for drawing inferences from our data. The data summarized using the descriptive analysis, hypotheses were formulated using inferential statistics, dispersion methods were used to measure the central tendency like mean, standard deviation, and variance using statistical package for social sciences ver 26.

Reliability methods: To test the internal consistencies and reliability of the survey instrument the reliability statistics Cronbach alpha, split-half correlation, Spearman Brown prophecy were measured to indicate all the items in the instrument related to the survey instrument [21]. The instrument was tested with 100 employees data using SPSS ver 26 and overall C-alpha was estimated as 0.70 . Sometime later the data for all the employees $(n=924)$ $\mathrm{C}$-alpha value was measured which considerably improved to 0.82 . The $\mathrm{C}$-alpha values for men ranged from 0.67 to 0.86 and for women 0.63 to 0.84 . The reliability statistics details were presented in Table 3 . All the $\mathrm{C}$-alpha values are $>0.6$ suggesting a strong internal consistency. The second reliability measure Spearman Brown Split-Half correlation and Spear Brown Prophecy were computed to assure the overall survey instrument reliability and the values indicate strong reliabilities.

Table 3: Reliability statistics of the survey instrument (C-alpha, split-half (odd even) correlation, Spearman Brown Prophecy)

\begin{tabular}{|l|c|c|c|c|c|c|}
\hline \multicolumn{1}{|c|}{ Factor } & \multicolumn{3}{|c|}{ Men } & \multicolumn{3}{c|}{ Women } \\
\hline C-alpha & $\begin{array}{c}\text { Split-half } \\
\text { Correlation }\end{array}$ & $\begin{array}{c}\text { Spearman } \\
\text { Brown } \\
\text { Prophecy }\end{array}$ & $\begin{array}{c}\text { C- } \\
\text { alpha }\end{array}$ & $\begin{array}{c}\text { Split- } \\
\text { half }\end{array}$ & $\begin{array}{c}\text { Spearman } \\
\text { Brown } \\
\text { Prophecy }\end{array}$ \\
\hline $\begin{array}{l}\text { Performance } \\
\text { Management System }\end{array}$ & 0.86 & 0.78 & 0.88 & 0.84 & 0.76 & 0.80 \\
\hline Personal Competencies & 0.74 & 0.65 & 0.79 & 0.72 & 0.63 & 0.76 \\
\hline $\begin{array}{l}\text { Knowledge Level } \\
\text { Competencies }\end{array}$ & 0.68 & 0.64 & 0.70 & 0.63 & 0.60 & 0.68 \\
\hline $\begin{array}{l}\text { Job-Knowledge } \\
\text { Competencies }\end{array}$ & 0.68 & 0.62 & 0.75 & 0.67 & 0.60 & 0.72 \\
\hline $\begin{array}{l}\text { Communication and } \\
\text { interpersonal } \\
\text { competencies }\end{array}$ & 0.67 & 0.66 & 0.80 & 0.66 & 0.62 & 0.76 \\
\hline
\end{tabular}

Relationship among the study variables: A Pearson's bivariate product moment correlation was run to assess the relationship between the performance management system and personal, job-related, knowledge level, and communication and interpersonal competencies for IT Enabled Service companies ( $=900)$. Preliminary analysis showed the relationship with both the variables normally distributed, as assessed by Shapiro Wilk test ( $p>0.05)$, and there were no outliners. There was a high positive correlation between performance management system and all the four employee competencies and is significant at 0.01 level (2-tailed, Table 4). And all four competencies are significant predictors of the performance management system. 
Table 4: Bivariate product moment correlation on Performance Management System, Job Related Competencies, Personal Competencies, Knowledge Level Competencies, Communication and Interpersonal Competencies (Over all $\mathrm{n}=900$ )

\begin{tabular}{|c|c|c|c|c|c|}
\hline \begin{tabular}{|l|} 
Factor \\
\end{tabular} & $\begin{array}{c}\text { Performance } \\
\text { Management } \\
\text { System }\end{array}$ & \begin{tabular}{|c|} 
Job Related \\
Competencies
\end{tabular} & $\begin{array}{c}\text { Personal } \\
\text { Competencies }\end{array}$ & $\begin{array}{c}\text { Knowledge } \\
\text { Level } \\
\text { Competencies }\end{array}$ & $\begin{array}{c}\text { Communication } \\
\text { and } \\
\text { Interpersonal } \\
\text { Competencies }\end{array}$ \\
\hline $\begin{array}{l}\text { Performance } \\
\text { Management } \\
\text { System }\end{array}$ & 1 & & & & \\
\hline $\begin{array}{l}\text { Job Related } \\
\text { Competencies }\end{array}$ & $.687^{* *}$ & 1 & & & \\
\hline $\begin{array}{l}\text { Personal } \\
\text { Competencies }\end{array}$ & $.701^{* *}$ & $.596^{* *}$ & 1 & & \\
\hline $\begin{array}{l}\text { Knowledge } \\
\text { Level } \\
\text { Competencies }\end{array}$ & $.698^{* *}$ & $.590^{* *}$ & $.603^{* *}$ & 1 & \\
\hline \begin{tabular}{|l|} 
Communication \\
and Interpersonal \\
Competencies
\end{tabular} & $.750^{* *}$ & $.631^{* *}$ & $.640^{* *}$ & $.654^{* *}$ & 1 \\
\hline
\end{tabular}

\section{RESULTS}

\subsection{Multiple Regression Analysis}

The four independent variable Job Related Competencies, Personal Competencies, Knowledge Level Competencies, Communication and Interpersonal Competencies entered simultaneously for the analysis using the enter method.

Table 5: Model Summary: Job Related Competencies, Personal Competencies, Knowledge Level Competencies, Communication and Interpersonal Competencies and performance management system (dependent variable) $(\mathrm{n}=900)$

\begin{tabular}{|l|c|c|c|c|c|}
\hline Model & $\mathbf{R}$ & R Square & $\begin{array}{c}\text { Adjusted R } \\
\text { Square }\end{array}$ & $\begin{array}{c}\text { Std. Error of } \\
\text { the Estimate }\end{array}$ & $\begin{array}{c}\text { Durbin- } \\
\text { Watson }\end{array}$ \\
\hline 1 & $.840^{\mathrm{a}}$ & .706 & .705 & .36543 & 1.522 \\
\hline \multicolumn{5}{|l|}{ a. Predictors: (Constant), Job Related Competencies, Personal Competencies, } \\
Knowledge Level Competencies, Communication and Interpersonal Competencies \\
and performance management system \\
b. Dependent Variable: PMS \\
b.
\end{tabular}

The multiple correlation coefficient, which is abbreviated to just $R$, is simply the Pearson correlation coefficient between the scores predicted by the regression model (i.e., the predicted scores) and the actual values of the dependent variable. In this model, $R$ is a measure of the strength of the linear association between these two variables and can give an indication as to the goodness of the model fit with a value that can range from 0 to 1 , with higher values indicating a stronger linear association. A value of $\mathbf{0 . 8 4 0}$, in this example, indicates a high level of association. However, that the multiple correlation coefficient, $R$, is not a common measure used to assess goodness of fit (Table5).

The $R^{2}$ is equal to $\mathbf{0 . 7 0 6}$ in from the table indicates that the addition of all our independent variables into a regression model explained 70.6\% (i.e., $0.706 \times 100=70.6 \%$ ) of the variability of our dependent variable, Performance (compared to the mean model). 
The $R^{2}$ is based on this study is considered a positively-biased estimate of the proportion of the variance of the dependent variable accounted for by the regression model (i.e., it is larger than it should be when generalizing to a larger population). However, it is still considered by some to be a good starting measure to understanding the results [22]. The adjusted $R^{2}$ which corrects for this positive bias in order to provide a value that would be expected in the population. The adjusted $R^{2}$ value at 0.705 is indicative of a high effect size according to Cohen's (1988) classification.

Statistical significance of the model: The significance value in ANOVA table is .000 which actually means that $\mathrm{p}<.0005$, and $\mathrm{P}<.05$ is statistically significant result and an addition of all independent variables leads to a model that is statistically significant, and predict the dependent variable better than the mean model and statistically significantly better fit to the data than the mean model. The results are $\mathrm{F}(4,900)=552.591, \mathrm{P}<.0005$; where $\mathrm{F}$ indicated that a comparison with F-distribution (F-test) is made, 4 in $(4,900)$ is degrees of freedom, 900 in $(4,895)$ indicate the residual degree of freedom, 552.591 is obtained value of the F-statistic i.e. F-value and $\mathrm{P}<$ .0005 is the probability of obtaining the observed F-value if the null hypothesis is true (Table $6)$.

Table 6: ANOVA summary of the Job Related Competencies, Personal Competencies, Knowledge Level Competencies, Communication and Interpersonal Competencies and performance management system

\begin{tabular}{|l|l|c|c|c|c|c|}
\hline \multicolumn{2}{|c|}{ Model } & $\begin{array}{c}\text { Sum of } \\
\text { Squares }\end{array}$ & df & Mean Square & F & Sig. \\
\hline \multirow{2}{*}{$1 \quad$} & Regression & 295.164 & 4 & 73.791 & 552.591 & $.000^{b}$ \\
\cline { 2 - 7 } & Residual & 122.720 & 895 & .134 & & \\
\cline { 2 - 5 } & 417.884 & 899 & & & \\
\hline
\end{tabular}

Table 7: Regression coefficients for Personal Competencies, Knowledge Level Competencies, JobKnowledge Competencies, Communication and interpersonal competencies and performance management system

\begin{tabular}{|c|c|c|c|c|c|c|c|c|}
\hline & \multirow[b]{2}{*}{ Model } & \multicolumn{3}{|c|}{ Unstandardized Standardized } & \multirow[b]{2}{*}{$\mathbf{t}$} & \multirow[b]{2}{*}{ Sig. } & \multicolumn{2}{|c|}{$\begin{array}{l}\text { Collinearity } \\
\text { Statistics }\end{array}$} \\
\hline & & B & $\begin{array}{l}\text { Std. } \\
\text { Error }\end{array}$ & Beta & & & Tolerance & VIF \\
\hline \multirow[t]{5}{*}{1} & (Constant) & .498 & .072 & & 6.950 & .000 & & \\
\hline & $\begin{array}{l}\text { Personal } \\
\text { Competencies }\end{array}$ & .210 & .023 & .235 & 9.285 & .000 & .498 & 2.009 \\
\hline & $\begin{array}{l}\text { Knowledge Level } \\
\text { Competencies }\end{array}$ & .176 & .020 & .220 & 8.629 & .000 & .490 & 2.042 \\
\hline & $\begin{array}{l}\text { Job-Knowledge } \\
\text { Competencies }\end{array}$ & .185 & .022 & .214 & 8.566 & .000 & .512 & 1.951 \\
\hline & $\begin{array}{l}\text { Communication and } \\
\text { interpersonal } \\
\text { competencies }\end{array}$ & .273 & .023 & .321 & 11.846 & .000 & .436 & 2.294 \\
\hline
\end{tabular}

Interpreting the coefficients: The regression equation for the model can be expressed as: $\mathrm{PMS}=$ bo (b1 $\mathrm{x}$ Personal competencies $)+(\mathrm{b} 2 \times$ Knowledge Level Competencies $)+(\mathrm{b} 3+\mathrm{Job}$ Knowledge competencies)+ (b4 x Communication and interpersonal competencies) 
Performance: $0.498+0.210$ (personal competencies) +0.176 (Knowledge level competencies) +0.185 (Job-related Competencies $+0.273_{\text {(Communication and interpersonal competencies) }}$

The coefficient value of stress personal competencies represents the change in the dependent variable PMS for one unit change in the independent variable personal competencies. For one unit change in personal competencies 0.210 units of PMS is positively improved, keeping all other variables constant If we consider standardized coefficients a beta value of 0.235 indicates that a change of one standard deviation in the independent variable personal competencies results in a 0.235 standard deviations performance management system will be positively improved, keeping all other variables in the model constant. In a similar way if we consider for unit increase of knowledge level competencies will increase 0.176 units of PMS positively improved. If we consider standardized coefficients, a change in one standard deviation in independent variable Knowledge level competencies improves the PMS by 0.220 standard deviations, and so on (Table 7).

Interpretation of the multiple regression analysis results: A multiple regression was run to predict effect on performance management system from personal competencies, knowledge level competencies, job-knowledge competencies, communication and interpersonal competencies a sample $(\mathrm{n}=900)$. There was linearity as assessed by partial regression plots and a plot of studentized residuals against the predicted values. There was independence of residuals, as assessed by a Durbin-Watson statistic of 1.522. There was homoscedasticity, as assessed by visual inspection of a plot of studentized residuals versus unstandardized predicted values. There was no evidence of multi collinearity, as assessed by tolerance values greater than 0.1 . There were no studentized deleted residuals greater than \pm 3 standard deviations, no leverage values greater than 0.2 , and values for Cook's distance above 1 . The assumption of normality was met, as assessed by a Q-Q Plot. The multiple regression model statistically significantly The multiple regression model statistically significantly predicted PMS, F $(4,900)$ $=552.591, \mathrm{p}<.0005$, adj. $\mathrm{R}^{2}=0.705$. All the four added statistically significantly to the prediction, $\mathrm{p}<.05$. Regression coefficients and standard errors can be found in Table 7 . This indicates to reject the null hypothesis and accept that There is a correlation between personal competencies, knowledge level competencies, job-knowledge competencies, communication and interpersonal competencies in a sample $(\mathrm{n}=900)$. All the variables are predicting the PMS significantly. Therefore We reject the null hypothesis $\mathbf{H}_{01}$ : Employee personal competencies does not influence the performance management system of IT Enabled Service companies, and accept the alternate hypothesis $\mathbf{H}_{11}$ : Employee personal competencies influence the performance management system of IT Enabled Service companies; reject the null hypothesis $\mathbf{H}_{02}$ : Employee knowledge level competencies does not influence the performance management system of IT Enabled Service companies and accept the alternate hypothesis H12: Employee knowledge competencies influence the performance management system of IT Enabled Service companies; reject the null hypothesis H03: Employee job-related competencies does not influence the performance management system of IT Enabled Service companies and accept the alternate hypothesis H13: Employee job-related competencies influence the performance management system of IT Enabled Service companies; and reject the null hypothesis $\mathbf{H}_{04}$ : Employee communication and interpersonal competency does not influence the performance management system of IT Enabled Service companies and accept the alternate hypothesis $\mathbf{H}_{\mathbf{1 4}}$ : Employee communication and interpersonal competency the performance management system of IT Enabled Service companies and the results are in line with the studies carried out by Prasad et al ([16][17][18]; Messah and Kamencu, [23].Magnolia Tilca et al [24] and Elijah Ng'ang'a Njuguna and Bula Hannah Orwa [25] who carried out the research using multiple regression analysis. 
Further, the post-hoc Tukey HSD results indicate no statistically significant differences on performance and employee competencies for the six age groups suggesting age is not a predictor of performance management system (Table 8) following the procedure of Assaad et. al. [26].

Table 8 Results from Tukey HSD post-hoc analysis

\begin{tabular}{|l|c|c|c|c|c|c|}
\hline \multicolumn{1}{|c|}{ Factor } & A & B & C & D & E & F \\
\hline $\begin{array}{l}\text { Performance } \\
\text { Management } \\
\text { System }\end{array}$ & $3.82 \pm 0.053$ & $3.78 \pm 0.051$ & $3.85 \pm 0.052$ & $3.72 \pm 0.055$ & $3.76 \pm 0.055$ & $3.78 \pm 0.058$ \\
\hline $\begin{array}{l}\text { Personal } \\
\text { Competencies }\end{array}$ & $3.89 \pm 0.061$ & $3.83 \pm 0.058$ & $3.92 \pm 0.057$ & $3.85 \pm 0.061$ & $3.85 \pm 0.061$ & $3.89 \pm 0.064$ \\
\hline $\begin{array}{l}\text { Knowledge } \\
\text { Level } \\
\text { Competencies }\end{array}$ & $3.86 \pm 0.070$ & $3.87 \pm 0.059$ & $3.88 \pm 0.069$ & $3.86 \pm 0.069$ & $3.91 \pm 0.063$ & $3.92 \pm 0.077$ \\
\hline $\begin{array}{l}\text { Job related } \\
\text { Competencies }\end{array}$ & $3.85 \pm 0.070$ & $3.83 \pm 0.062$ & $3.98 \pm 0.057$ & $3.88 \pm 0.064$ & $3.88 \pm 0.059$ & $4 \pm 0.06$ \\
\hline $\begin{array}{l}\text { Communication } \\
\text { and } \\
\text { interpersonal } \\
\text { competencies }\end{array}$ & $3.88 \pm 0.064$ & $3.9 \pm 0.060$ & $3.97 \pm 0.057$ & $3.86 \pm 0.068$ & $3.94 \pm 0.061$ & $3.94 \pm 0.071$ \\
\hline
\end{tabular}

Values are means \pm SEM.

Means in a row without a common superscript letter differ $(P<0.05)$ as analyzed by oneway ANOVA and the TUKEY test. As they no superscripts no statistically significance differences among the groups. Age groups (Years): 20-25; B: 26-30; C: 31-40; D: 41-50; E: 51$60 ; \mathrm{F}:>60$

\section{DISCUSSION}

The authors carried out this study as there are very limited research available on predicting the effect of personal competencies on performance management system. The presented results in line with the several performance management system studies carried out by various researchers using multiple regression analysis. The Omboi Bernard Messah and Shadrack M. Kamencu (2011) carried out a study using regression analysis to predict the factors that Effect of Performance Appraisal Systems on Employees in Kenya Tea Development Agency using a survey and our results more or less similar to the study. Survey research to have some problems of reliability of the survey instrument and has author has no knowledge whether the respondents spent considerable to read the question by question or just selected the answers arbitrarily. However, the authors are able to overcome this problem by applying the reliability statistics Cronbach alpha and Split-half statistic indicated that there is a strong reliability and internal consistency in the survey instrument. The authors also faced the problem of absence of related research publications and models. The model was developed with the limited available models and appropriate survey instrument was prepared and the empirical study was carried out. The survey instrument was published using google corms and hard copies were provided for the needed. To conclude that the four employee competencies Personal Competencies, Knowledge Level Competencies, Job-Knowledge Competencies, Communication and interpersonal competencies.

\section{CONCLUSION}

The design and implementation of the performance management system in any organization depend on its goals, vision, mission and business model. However, for implementation the employee positive behavior is must. The author suggest the performance appraisal should be at 
least twice a year with relevant feedback. In yearly performance appraisal system the management need wait for a year and this is not advisable because volatile business operations and rapid technology development. The authors believe the presented approach can be used for similar type of studies in any organization to study the effect similar independent variable on performance management system.

\section{DECLARATION OF CONFLICTING INTERESTS}

The authors received no potential conflicts of interest with respect to the research, authorship and/or publication of this article.

\section{FUNDING}

The authors received no financial support for the research, authorship and/or publication of this article.

\section{REFERENCES}

[1] Mangipudi M R, Prasad, KDV, Vaidya, R. Optimization of Human Resources: Does Human Resource Pooling in an Organization Help in Improving Capacity Building and Efficiency? A Case Study. Journal of Human Resource and Sustainability Studies, 2019, 7(3), 397-405.

[2] HR HelpBoard, Performance Management Systems https://www.hrhelpboard.com/performance-management/performance-managementsystem.htm, 2018

[3] Sameeksha Jain and Aditya Gautam. Performance Management System: A Strategic Tool for Human Resource Management, https://www.researchgate.net/publication/305720304 Performance_Management_System_A_Strategic_Tool_for_Human_Resource_Management, $201 \overline{4}$

[4] Randor McGuire. Performance management in the public sector: fact of fiction? International Journal of Productivity and Performance Management, 2004, 53(3):245-260.

[5] Furnham, A. Performance management systems, European Business Journal, 2004, 16(2):83-94

[6] Johnson HT, Kaplan RS. The rise and fall of management accounting. IEEE Engineering Management Review, 1987 3(15), 36-44. https://doi.org/10.1109/EMR.1987.4306297

[7] Hewitt Associates, the Impact of Performance Managem3ent on Organizational Success. Hewitt Associates LLC, 1994

[8] Simons, R, Performance measurement and control systems for implementing strategy: text \& cases, Prentice Hall, Upper Sadle River, NJ, 2000

[9] Holloway, J., Lewis, J. and Mallory, G. (Eds), Performance measurement and Evaluation, Sage, London, 1995

[10] Roberts I, Reward and performance management. In I. Beardwell \& L. Holdenb (Eds.). Human Resource Management: A contemporary approach ( $3^{\text {rd }}$ Edition). Edinburgh, Pearson, 2001

[11] Watkings, R. Designing for performance, part3: Design, development and improve.Performance Improvement, 2007b, 46(4):42-48.

[12] Helm C, Holladay CL, Tortorella FR. The performance management system: applying and evaluating a pay-for-performance initiative. Healthcare Management, 2007, 2(1):49-62;

[13] Sole F, A management model and factors driving performance in public organizations. $\begin{array}{lllll}\text { Measuring } \quad \text { Business } \quad \text { Excellence, 13(4), 2009, pp } & \text { 3-11 }\end{array}$ https://doi.org/10.1108/13683040911006747 
Employee Competencies as the Predictors of the Performance Management System: An Empirical Study in it Enabled Service Companies around Hyderabad

[14] Bhattacharjee S Sengupta S. A study of performance management system in a Corporate Firm, VRSD-IBJMR 2011, 1(8):496-513.

[15] Mamatha Ch. Prasad, KDV. Employee Performance A Function of Social Support and Coping: A Case Study with Reference to Agricultural Research Sector Employees Using Multinomial Logistic Regression. IOSR Journal of Business and Management 201719 (7): $12-21$.

[16] Prasad KDV, Rajesh Vaidya, Association among occupational stress factors and performance at workplace agricultural research sector employees at Hyderabad, India. Pacific Business Review International 2018 10(7):27-36

[17] Prasad, KDV. \& Vaidya, R, Causes and Effect of Occupational Stress and Coping on Performance with Special Reference to Length of Service: An Empirical Study Using Multinomial Logistic Regression Approach. Psychology, 2018, 9, 2457-2470 -2470.

[18] Prasad KDV, Vaidya, R. Causes and effect of occupational stress and coping on performance and psychological well-being among the Agricultural Research Sector: An Empirical Study using Multinomial Logistic Regression Approach. Helix Journal - The Scientific Explorer. 2018, 8(6), pp 4114-4119. DOI 10.29042/2018-4114-4119

[19] Turóczy Zsuzsannaa and Liviu Marian. Emerging Markets Queries in Finance and Business Multiple regression analysis of performance indicators in the ceramic industry. Procedia Economics and Finance Writinghub, To assess the impact of performance management system on employee, 2012, 3, pp 509-521

[20] Writing Hub, Performance case study of Sainsbury's, https://www.slideshare.net/writinghub/to-assess-the-impact-of-performance-managementsystem-on-employee-performance-case-study-of-sainsburys, 2015.

[21] Gay LR, Mills GE, Airasian P, Educational Research: Competencies for Analysis and Applications. Columbus: Merrill Greenwood, 2006

[22] Draper, NR, Smith H, Fitting a straight line by least squares. Applied regression analysis, 1998, 1, pp 5-46.

[23] Messah ob, and Kamencu sm. Effect of Performance Appraisal Systems on Employees in Kenya Tea Development Agency: A Survey of Selected Tea Factories in Meru CountyKenya. Research Journal of Finance and Accounting 2011, 2(3):16-35

[24] Tilca, M, Mar, E, Apatean, A, A model to measure the performance of human resources in organizations. Studia Universities "Vasile Goldis" Arad. Economics Series 2018, 28(1):57 $-73$

[25] Njuguna en, Orwa BH. Antecedents of Performance Appraisal and Organizational Performance in Water and Sanitation Companies in Kenya:A Case of Murang'a Water and Sanitation Company limited. International Journal of Business and Economics Research. 2015, 4(5): 250-263, doi: 10.11648/j.ijber.20150405.14

[26] Assaad h, Zhou, L, Carroll RJ, Wu G, Rapid publication-ready MS-Word tables for oneway ANOVA. SpringerPl.us 2014, 3:474

[27] Dr. L. Vijay and B. Jayachitra, Effectiveness of Performance Management System, International Journal of Advanced Research in Management (IJARM), Volume 1, Issue 1, January- June (2000)

[28] Sunidhi Sumedha Bhosekar and Dr. Anupama Ghoshal, Employee Perception of Performance Management Practices in Indian Banks. Journal of Management, 5(4), 2018, pp. $40-49$ 